\title{
Filming Resistance: A Hezbollah Strategy
}

Walid el Houri, University of Amsterdam

Dima Saber, Université Paris 2

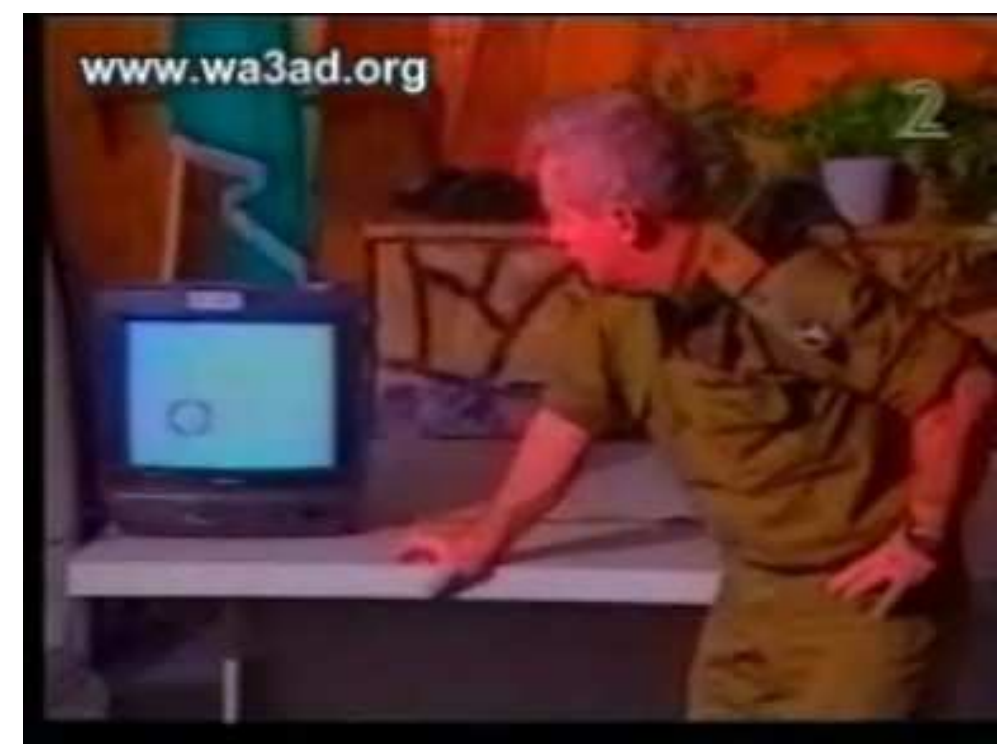

An Israeli officer watching a Hezbollah filmed operation

Hezbollah's filmed operations are one of the key media texts that constitute the group's discourse of resistance and their strategies of representation in the context of the ArabIsraeli conflict. In 1986 Hezbollah introduced an innovation in their strategies of resistance. Their militants filmed one of their armed operations in the occupied southern Lebanon and broadcast it on television. This film, followed by numerous others, had an impact on the growing popularity of the movement and on the construction of their image in the minds of the public. First broadcast by national media, they are now placed in online archives accessible to anyone at any time through Hezbollah's internet sites. By looking at these two aspects of the film presentation and reception (as event and as archives) this paper analyzes their function that goes beyond simple journalistic value to become part of a narrative of identity and self representation.

Stemming from Michel Foucault's and Edward Said's notions of power and knowledge, the paper looks at these films as a strategy of resistance and as an attempt of self 
representation that defies and inverts the established relation of power and domination. The films act as a metaphor of empowerment of a dominated self presented as the "one who sees", the "one who allows to see", and the "one who is seen". Thus they no longer act as a representation of reality but as what Daniel Dayan calls "monstration": this reality only exists through the way it is shown (Dayan 183).

\section{A Genealogy of the Filmed Operations}

The filmed operations are edited footage shot by what the party designates as their "military media", depicting military operations carried out by the Hezbollah fighters against the Israeli army and its collaborators in the occupied southern Lebanon. These films are one of Hezbollah's various media productions that constitute the party's strategy of representation. The films were first broadcasted on television screens in Lebanon, Israel and the Arab world as journalistic material, putting forward their indexical value. In this case the filmed operations constitute the event and their function is defined accordingly to this mode of presentation. However, the films have another mode of existence, one that is defined by a different mode of presentation once they are placed in online archives (DVD, VHS, internet websites). At this moment these films loose their value as news and acquire a new value that we will explore throughout this paper.

One definition of an event is that it has the capacity to initiate and generate something new and unpredictable; in this sense the event represents a rupture. This rupture impels the reconstruction of a frame prompted by its occurrence; a transition from the unpredictable possibility, to a predictable possibility that perturbs the prevailing relation of power in a conflict (Foucault 2004, 410-3). In this sense, Hezbollah's filmed operations represent an event inasmuch as they are a rupture in the course of the conflict's representation.

This shift in presentation entails a change in the value, function, and meaning of these films. This paper focuses on their meaning when placed in such archives. While the event 
has the capacity to initiate and generate something new and unpredictable, a rupture that perturbs the prevailing relation of power in a conflict, the archives, on the other hand, entail a notion of past and memory, an event that is fixed in a past time, a historical moment that is framed by the way it is archived. Archives put forward a representation of self, and a common memory shaped by the politics of archiving.

We chose to look at three specific videos. These were chosen for several reasons. First is the number of viewers, an important factor that pertains to the reception of these films. Each one of the three chosen videos has an average of 12000 views on the Hezbollah website (www.wa3ad.org) alone (they can also be accessed through other Hezbollah websites as well as youtube and google video) Secondly, the three chosen videos are representative of three different genres often seen in the totality of the video operations: footage showing Israeli soldiers or vehicles falling prey to the Hezbollah explosive attacks (in these films we only see the Israelis in a voyeuristic perspective), footage of Hezbollah combatants attacking Israeli outposts, and footage of Hezbollah combatants facing Israeli soldiers. Third, the films were chosen for the period in which they were produced, during the early 90s when the discourse of "resistance" that Hezbollah was preaching was being constructed and rapidly gaining ground among the Lebanese and the Arabs publics. This period is central to the emergence of the Hezbollah discourse of "resistance" especially after the assassination of their former Secretary General Abbas alMoussawi in 1993 and the beginning of Hassan Nasrallah's leadership of the party. Throughout this decade the Hezbollah will focus on promoting a narrative of "resistance" and developing their media capacities by introducing the "Channel of the resistance", AlManar in 1991 (Mohsen; Exum; Ajemian). It should be noted that when resistance is used between quotation marks it refers to what the Hezbollah calls resistance - the basis on which their discourse and identity are constructed. Otherwise, resistance as such will refer to the notion of resistance designated by Foucault as a discursive force (Revel).

One cannot talk about the Hezbollah filmed operations without inserting them in the larger context of a complex discourse that has been growing since the late 80s. It is a discourse the Hezbollah call of "resistance", a culture, as their secretary general calls it, 
that the party has been preaching and articulating for the last two decades. The filmed operations are part of this general discourse and their meaning, function, and strategy must be read according to their political, cultural, and social history. In the following paragraphs we will look into the historical context in which these films flourished as a landmark of Hezbollah's image in the Arab world.

The emergence of these films can be read along the lines of the video revolution that took place in the 1980s. In fact, the year 1982 is perhaps the most significant date in the genealogy of these films. That year, two major events took place and they were to have a great influence on the subsequent rise of the Hezbollah and their media. The first one was JVC's introduction of the new VHS-C video format and later Sony's introduction of the Betacam and Betamax video formats. The second was Israel's large scale invasion of Lebanon that led to the occupation of Beirut. The violent invasion triggered new forms of resistance that were based on religious zeal rather than leftist and nationalist ideals (Corm 32-7); The Hezbollah was soon born as a reaction to Israel's 1982 invasion.

The new video technology provided a whole new dimension to the production of images; the largest impacts were both economical and technical. Video, contrary to cinema, is cheap and easy to handle. The video revolution thus democratized the production of images and led to the birth of new forms of expression that were to flourish in the 80s. The camcorders also provided a new political use of images, a moving witness that could easily be broadcasted. The use of video cameras by different kinds of political protesters became more and more common; it was a form of "citizen journalism" that Hezbollah adopted and adapted to become "militant journalism".

In this sense Hezbollah's filmed operations represent the meeting point of a rising religious discourse that introduced new strategies of communication and resistance and the role of new media in providing the tools for the propagation of this discourse. In 1986 Hezbollah used the new video technology to film their first operation and broadcast it on Lebanese television screens. While the invasion of Lebanon was the direct reason for the emergence of Hezbollah, the new video technology introduced new ways of manipulating 
and using images, a more accessible and easily handled technology which would metaphorically be the Kalashnikov of image production. In other words the less expensive and poorer quality video camera seems adequate for guerilla action like the Kalashnikov has been for decades since it was introduced and associated to guerilla warfare all around the world.

By the end of 1990, the Lebanese civil war came to an end as was the case of many conflicts in the world. The collapse of the Soviet Union was the end of long decades of Cold Wars that burnt many a country. The fall of the Soviet Union had a great impact on the Arab and Muslim world and made way for the rise of new forces of resistance fueled by religious fervor rather than the myriad forms of Marxism that had flourished in the previous decades (Corm 78-80; Samaha 127-138). The accord that ended the Lebanese civil war put an end to all the militias except the Hezbollah which was recognized as the legitimate force of resistance against the Israeli occupation of southern Lebanon (Traboulsi 423). This shift was the start of a new strategy of resistance that the Hezbollah adopted in the 90s: to make themselves heard, to advance their narrative, and to gather support in Lebanon and the Arab world as a model of resistance (Mohsen; Ajemian). The filmed operations represent an intrinsic and major part of the party's efforts to advance their self image.

The 90s were the decade when support for Hezbollah grew immensely among the Shiite community in Lebanon especially after the assassination of their former Secretary General Abbas al-Moussawi and the rise of the charismatic Hassan Nasrallah to power (Nasr 112-7; Mohsen). During the 90s the Hezbollah intensified their attacks against Israeli targets in southern Lebanon, however, at the same time they carried out a new and efficient strategy of representation in order to advance their narrative and gather support among the Lebanese community as well as the Arab and Muslim ones. The Hezbollah launched a TV channel, Al Manar, explicitly aimed at advancing the values, ideas, and culture of the "resistance" (Mohsen, Ajemian, Exum).

\section{The Films}


We have chosen 3 films, based on three strategies of representation and communication, out of which we have isolated three sequences representing respectively the other, the self, and the confrontation between the two.

We will therefore "read" these 3 sequences on two levels; first in the shadow of Daniel Dayan's rereading of Austin's "speech acts" theory, where the "showing" becomes an integral part of the "saying" and thus the "doing" (Dayan 165). Second, following Foucault's notions of discursive formations, of power and knowledge, where we will "read" the Gaze as a central force of resistance allowing a shift in the power balance between the two conflicting discourses (Foucault 1971; 1979).

By putting these videos online and transforming Austin's "speech acts" into Dayan's "Gaze acts", the Hezbollah are creating a new "public arena" where a new common imaginary is at play.

Every speech implies the construction of a self image. And the starting point of our analysis is to look at these three videos as "speech acts" by which the Hezbollah constructs its own self image. Two technical similarities should be noted in these videos; first the music, a revolutionary rhythmic common to war themes. Second, the poor quality of the image; both grainy and shaky, these images seem to be reminding us every second that we are witnessing "reality".

In this reality two actors are at play: a self vs. an other. And it is this motion that goes from the representation of the other to that of the self all while depicting a constant confrontation between the two that we have chosen to "give you to see".

The Dabsheh Tank video 29/10/1994 

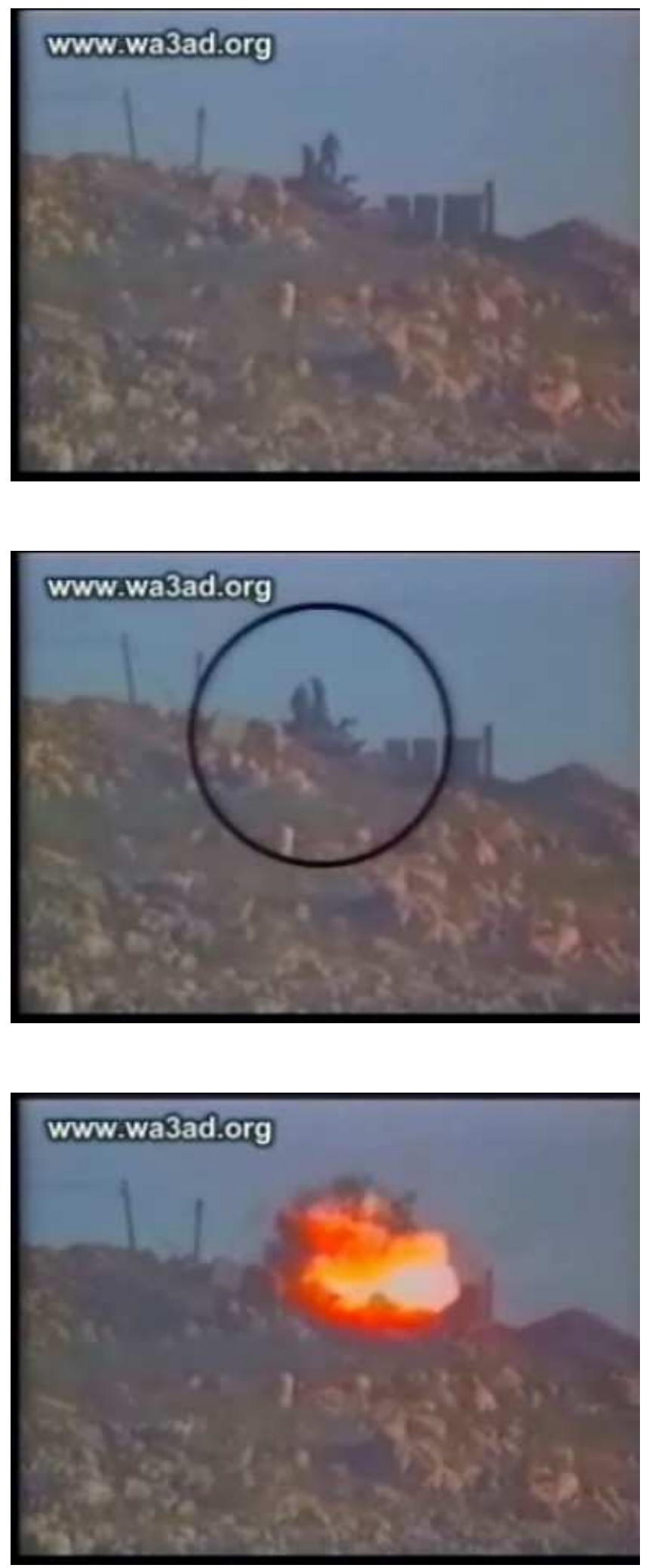
In the first video, the other is seemingly the object to be seen. There is an explosion, and two Israeli soldiers are killed. But one detail, the circle, tells us there is another presence to be sought: The eye of the moving camera; the eye of the self.

First, the circle tells us where to look, a first "speech act". Then, the slow motion adds fiction to the video and shows us precisely what to look at. This meeting of fiction and reality transforms all representations into what Daniel Dayan calls "monstrations"/ or "showing". At this moment we can substitute Austin's saying is doing, by Dayan's showing is doing. In this sense, reality only exists through the way it is shown.

In this reality, the self is shown as "omnipotent"; it is secretly filming the other in a clear relation of power since it is the only one who knows the other will soon die.

But, the circle also implies another presence; that of Hezbollah's public who is invited to witness a particular moment in the spectacle of their war against Israel; the moment where the self gets to defeat the dominant other.

In this sense, the public is drawn closer to this confrontation, offered to share the same emotions as the one looking though the camera, only they are looking through a screen.

This is when the public becomes, what Dayan calls, an "extension or even a manifestation of an $u s "$, composed by those who choose to identify with the man holding the camera (Dayan 183).

Storming the Ahmadyeh outpost video 29/6/1996

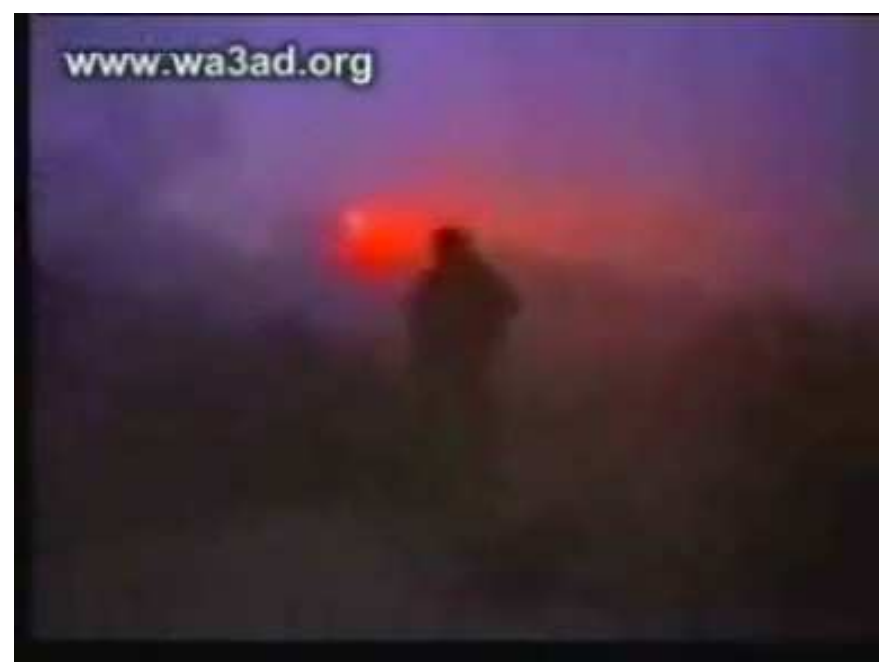



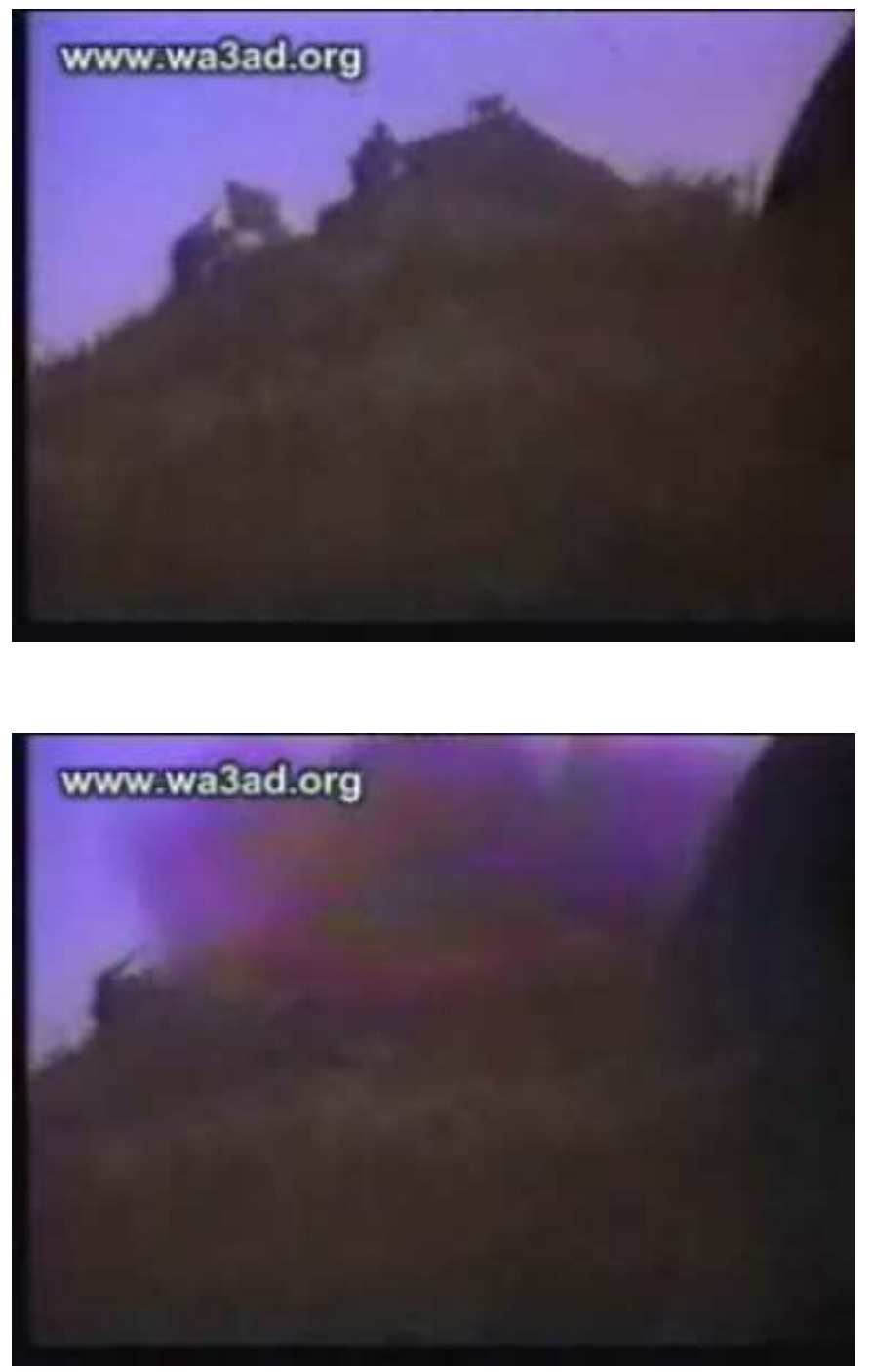


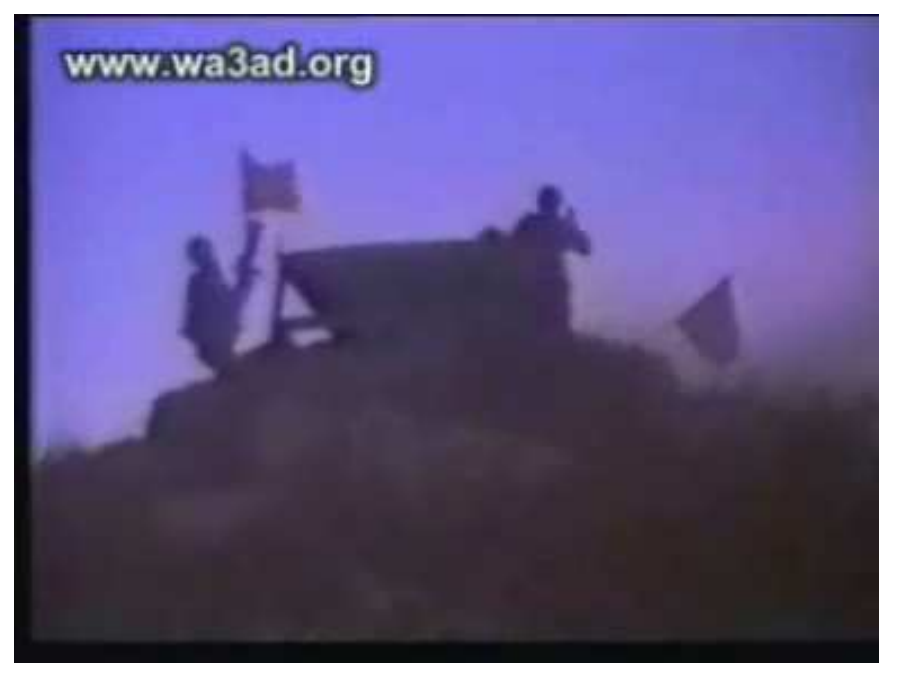

If in the first video, the explosion and the death of the two Israeli soldiers imply a victory of the self over the other, we are invited in the second to accompany the self on its passage towards victory.

After a long paths filled with dust, shrieking bullets, detonations and all the noises of war, we can distinguish a fighter leading his way towards the light emanating from an explosion. Then, three men approach what seems to be their target; an explosion, and then a voice claims victory by shouting "Allah Akbar", and a flag is raised.

The other is absent from the picture. The semantic field of victory leaves no space but for a victorious self. Articulated on two symbolic layers, the religious (Allah Akbar) and the nationalist (the flag), Hezbollah's self representation confirms what had been sensed but not seen in the first video, a self celebrating its moment of victory over the dominant other, a moment the same public is also invited to share.

The Tallouseh operation video 15/1/1993 

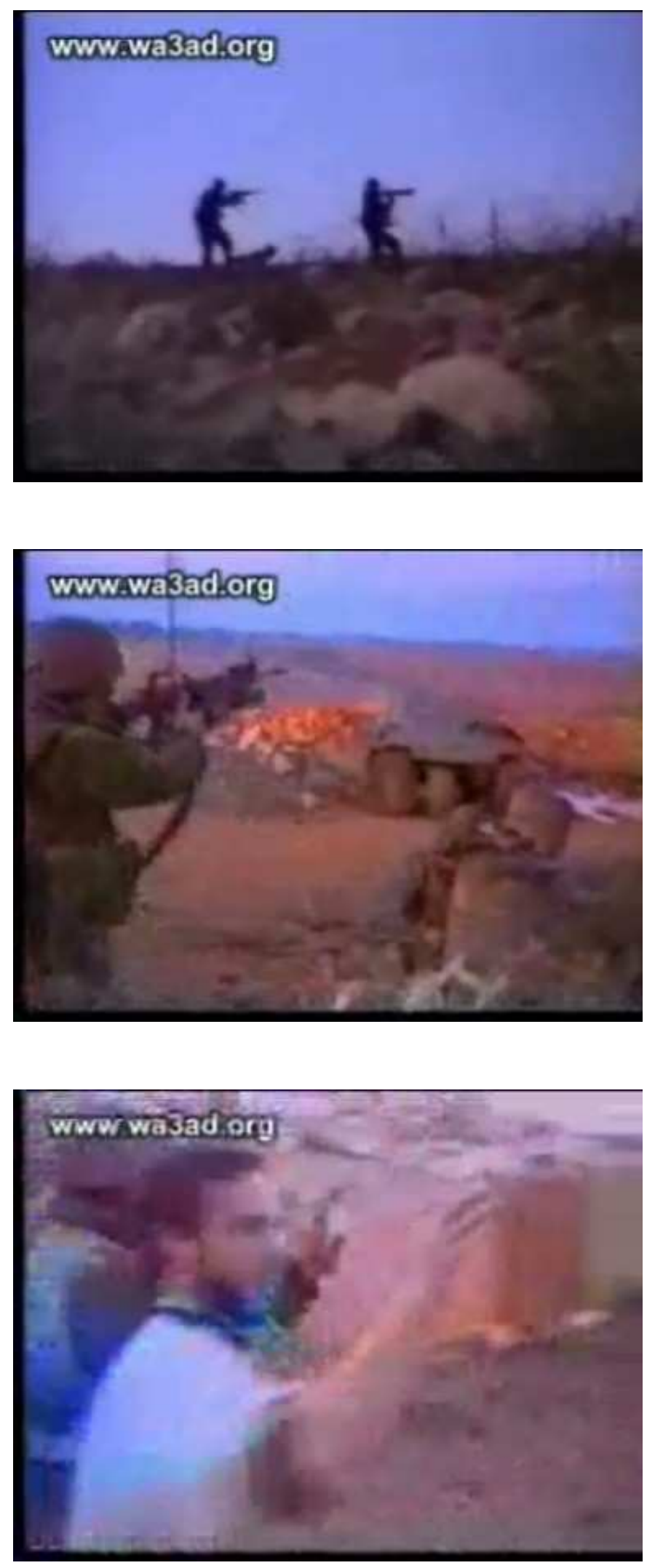


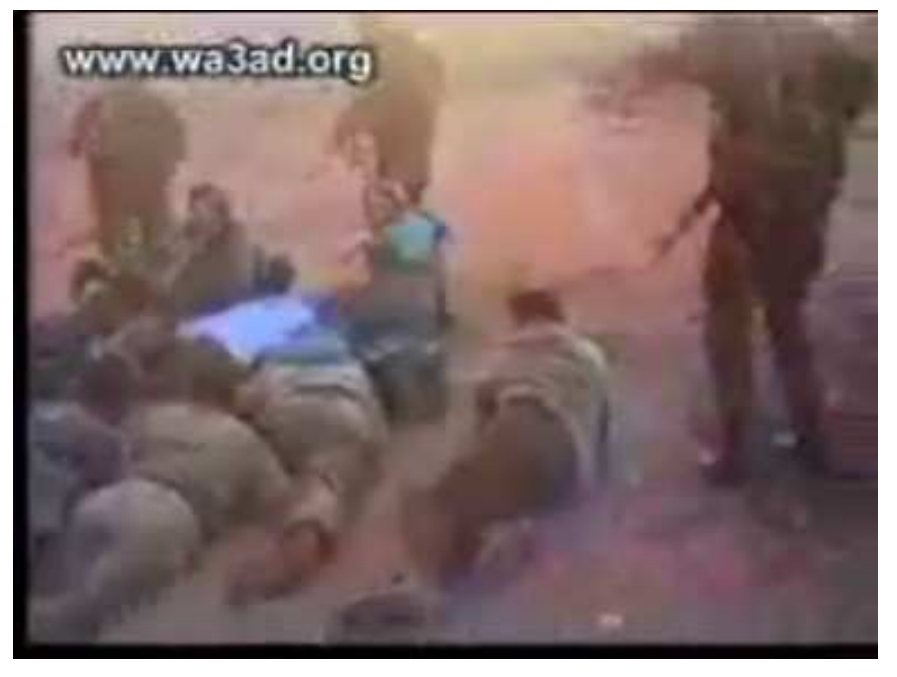

Now that we have seen visually isolated self and other, the third video seizes the moment when the first confronts the second in the same image.

A visual rhetoric allows the celebration of a dominant self, and thereby a dominant $u s$.

The $u s$ is shown wearing arms, well prepared, confident and severe. The other is on the contrary disarmed, docile, and howling. Obviously taken by surprise on its own ground, the other is seen dominated by the self; the video ends with Hezbollah fighters piling the captured soldiers on the ground.

The contrast is obvious and shows the very meaning that the two previous videos had implied. However, there is always an absent image haunting images (Lambert 103); the image of a self dominated by the other, the image of a militia dominated by an organized army, Hezbollah dominated by Israel. In these videos it is precisely this relation of power that is inverted since the Hezbollah has become the one who sees, is seen, and allows to see.

\section{The Filmed Operations as Discourse}

While these films correspond to a discourse of resistance, and more broadly to a larger dispositive of power used to subvert the domination of the other (Wodak 41; Deleuze 45), their genealogy is rooted in the political, cultural, and technological changes that took place in the $80 \mathrm{~s}$ and $90 \mathrm{~s}$. The films, as was shown above, assume a position of power vis 
a vis the Israeli other. Thus, they place Hezbollah in the panoptic equation as the one who sees, watches, and shows. In this sense, they assume power over surveillance but also a power over representation.

Foucault defines dispositive as "a heterogeneous ensemble which covers discourses, institutions, architectural institutions, reglemented decisions, laws, administrative measures, scientific statements, philosophical, moral or philanthropic teachings, in brief, what is said and what is not said." The dispositive itself is the net that can be woven between these elements. In this sense it is the shell which envelops both discursive and non-discursive practices and materializations (Wodak 39-40).

The shift in the presentation of the films from being broadcasted on TV as part of the news section to being "relegated" to online archives (DVD, VCD, VHS, Internet) corresponds to a shift of meaning and function of these films within the discourse and dispositive of Hezbollah.

In other words, when the films were broadcasted as news they carried a journalistic value, an indexical value telling the audience that this actually took place. They were a proof. In this case they represented an event. Their power is both indexical and performative (Dayan).

Placed in archives, the films loose their journalistic value or newsworthy value. Even though they remain indexical and performative, they gain a new value, that of self representation. The films are no longer seen for their newsworthiness, but both as proof that this happened one time, and can happen any time, and as a constant reminder of Hezbollah's narrative of empowerment. The films thus construct and sustain a common memory and a visual rhetoric that consolidates Hezbollah's narrative where self is constantly empowered (Mohsen). The films then become a representation of a reality that is contending the dominance of the prevalent discourse. The films are thus a site of the struggle over discourse (and truth) and within discourse. 
In his "Orientalism" Said quotes Marx's epigraph "they cannot represent themselves; they must be represented" (Said 21; 293; Zizek). Said refers to this equation when talking about the exercise of domination through the power of representation. The filmed operations are, as we have seen, one of Hezbollah's strategies to break this inability of self representation by acquiring an "eye", a "Gaze", and a power to contend the domination of the other.

They are not only able to represent themselves but to provide a different representation of the other as well. A new balance of powers thus arises, or at least is negotiated through discourse and discursive practices. The struggle becomes also over representation: a conflict of images and narratives between two opponents trying to win the battle of representation that is taking place in the realm of media.

In this paper we will not go into the details of the discourse of Hezbollah when it comes to the historical narrative, the idea of justice, right, and morality. However, it might be relevant in order to understand the perspective we are using when talking about Hezbollah's discourse of "resistance" to remind of Foucault's statement in a discussion with Noam Chomsky: "one makes war to win, not because it is just" - even though groups often justify their actions by a claim of justice derived from their narrative of history. Foucault says:

"Rather than thinking of the social struggle in terms of 'justice', one has to emphasize 'justice' in terms of the social struggle (...) It seems to me that the idea of justice in itself is an idea which in fact has been invented and put to work in different types of societies as an instrument of a certain political and economic power or as a weapon against that power. But it seems to me that, in any case, the notion of justice itself functions within a society of classes as a claim made by the oppressed class and as justification for it." (Chomsky)

In this perspective Hezbollah's struggle is also based on an idea of justice, of moral superiority and a long lasting fight against oppression. Justice within this scope belongs to the discourse that justifies this struggle for power. 
Hezbollah's strategy of resistance is articulated around a system of knowledge and power that seeks a reformulation of the power balance in the Arab-Israeli conflict, or the Islam/West conflict for that matter. The party has become a symbolic structure whose force is exercised in great part by discursive elements rather than non-discursive ones. In short, what we will call the dispositive of power, combines in Hezbollah's case a number of discursive and non-discursive elements that together form a strategy of resistance that we try to understand in this article by shedding light on the filmed operations as a key element of Hezbollah's media discourse.

\section{Two Messages, Two Audiences}

As stated in the introduction, 1982 was the year VHS-C was developed, and the eighties were the decade that witnessed the fast spread of video which quickly became accessible to consumers and institutions alike. This development is an important factor in the development of the discourse of Hezbollah namely in its use of new media and the visual capacities provided by the video technology. Paul Virilio argues that war "cannot break free from the magical spectacle because its very purpose is to produce that spectacle." In other words it consists, as he writes, "not so much in scoring territorial, economic or other material victories as in appropriating the 'immateriality' of perceptual fields" (Virilio 5-7). The power of the Hezbollah films lies precisely in the perceptual field, as a spectacle of power, as an exhibition of power that the following paragraphs will seek to understand its impact on two audiences.

In a paper on the Spectacle of War and insurgent video propaganda Andrew Exum writes: "Hizbullah soon discovered that its broadcasts had an effect not just on the Lebanese population but on the Israelis as well. "On the field, we hit one Israeli soldier," one Hizbullah official explained. "But a tape of him crying for help affects thousands of Israelis ... we realized the impact of our amateur work on the morale of the Israelis." (Exum) 
The Hezbollah's media production is explicitly part of their war against Israel. In fact in the official discourse of the party, they speak of psychological war, and even of media war. In this perspective the films are made for a double purpose and for two audiences simultaneously. They address two audiences with radically different frames of reference. On the one hand the Israeli public whose reception of these films is part of a specific strategy based on the power of the gaze and the spectacle of power (the exhibition of power); in this context the films are meant to reflect a public punishment or a public exercise of punitive and warning "justice" (a public display of the power to punish) similar to the spectacle of the scaffold that Foucault describes in Discipline and Punish (Foucault 1979, 33-4). However, the films also exercise a disciplining force that places the Hezbollah in the panoptic equation (ibid. 195-228). On the other hand, these films are addressed to the Hezbollah public whose frames of reference are founded on the narrative of Ashura ${ }^{1}$ and another view of the Arab-Israeli conflict in which they see themselves as one of its major victims. In this case the films have a role in rearticulating the group's narrative of common suffering, and struggle. It reassembles the group around a ritual of looking at themselves and at the others and remembering the values and narrative that the Hezbollah keep reasserting.

The discourse of Hezbollah is firstly religiously motivated, it carries a divine promise of success derived from a verse of the Koran "enna hezboullah hom al ghaliboun" (Hezbollah - the party of God - are the victorious). This initial aspect of the party's name provides a new sense of empowerment to a group of historically marginalized people: the Shia.

If the films are presenting a narrative of empowerment it is not only by portraying victory over death but victory in death. This is where the narrative of Ashura becomes central for the understanding of the messages conveyed by the videos. Ashura is not simply a ritual

\footnotetext{
${ }^{1}$ Ashura is the tragedy around which the Shiite identity is constructed. It is the commemoration of the martyrdom of Hussain, the Prophet Mohammed's grandson and Imam Ali's son, in Karbala (modern day Iraq) on the $10^{\text {th }}$ of the month of Moharrem 680AD at the hands of the Khalifa Yazid's army. For Shia this is the most important religious day and represents the split of Islam in two major branches (Shia and Sunni). The narrative of Hussein's gruesome death is remembered in written and spoken texts as well as in some reenactments of the events that led to the final martyrdom as a reminder of the Shia values and principles.
} 
enacting the tragedy around which the Shiite identity is constructed but also represents the fundamental system of values for the Shiites that the Hezbollah keep reasserting in their media discourse ${ }^{2}$. The meaning of martyrdom, honor, defiance, resistance, and self sacrifice all appear in both Ashura and Hezbollah's narratives (Nasr 132 - 34). The Shiite political ideologies have often used the Ashura narrative as a metaphor for their present suffering and the case of Iran is perhaps the most significant example in modern times (ibid. 119-145).

When Hussein, son of Ali and grandson of the Prophet Mohammed, willingly encountered death when outnumbered in the battle of Karbala, his act will resonate in Hezbollah's portrayal of its own struggles against a much larger enemy both in number and in equipment. The men we see in the filmed operations are all "soldiers of Hussein", they all chose death rather than humiliation as the famous Shiite motto that the Hezbollah adopted as theirs goes "hayhat menna el zolla" (literally translated as away from us is humiliation). This fundamental aspect of the frame of reference of Hezbollah's audience is of utmost importance in order to understand the meaning that these films are conveying for the public of the party.

It should perhaps be noted that images from the filmed operations are very often used in Hezbollah's music video clips as a constant reminder of the successes of the party's military wing, and the power that they try to constantly show to their audiences in Lebanon and the Arab world but also to the Israeli audience since the Al-Manar channel started broadcasting via Satellite in May 2000 (The launching of Al-Manar via satellite coinciding purposefully with the date of the Liberation of the South of Lebanon, the Channel started its satellite broadcast with a special day long coverage of the Liberation). (Mohsen)

\section{Resistance and Terrorism}

\footnotetext{
${ }^{2}$ On the Shia ritual of Ashura and the story of Karbala as well as the Shia belief system see Vali Nasr, The Shia Revival, Chapter 1.
} 
The exhibition of power relates directly to the notion of terrorism. In this sense, terrorism is the way exhibition of power is perceived by the one on whom this power is exercised. Terror in this sense is a visual war strategy. While it is terror on the one hand, it is a celebration of power and resistance on the other. The filmed operations are in this sense representative of the complex opposition between terrorism and resistance. While one public sees the films as an act of terror, the other public sees it as a celebration of justice, resistance and legitimate power. Terror is, in this case, a strategy that corresponds to the power of the perceptual fields described by Virilio (Virilio 5-7) whereas the resistance of some becomes the terror of others (Dayan).

As the party calls its own discourse one of "resistance", the strategies by which it transgresses the prevalent dominant power build on the strategies of the very power they are transgressing (the Israeli portrayal of their own military power or the American exhibition of military force in the Iraq war for example can both be compared to the Hezbollah filmed operations). The party is advancing new systems of values and truths to counter the ones imposed by the West. It does so by using similar strategies, tactics, and means but advancing fundamentally different values and narratives. The most important aspect of this discursive conflict is the differing definitions and meanings of general values such as freedom, democracy, and justice. In other words, the resistance builds on the very forces that the dominant power exercises and contends their significance and impact (Foucault 2004, 390-1; 406-9). It is the case when the notion of freedom, which represents a backbone of the Western discourse, is understood as individual social freedom in liberal democracy while understood as the group's freedom from foreign influence by the nationalist and Islamic discourses (Dawisha 70-1). The same goes for democracy which is a notion that Hezbollah adopted in their narrative as being the free choice of people to be represented by what the West calls terrorist groups.

The issue becomes one of understanding the relation between resistance and terrorism. The films themselves are reminiscent of this opposition. Their reception, following the cultural recognition of the two targeted groups is exemplary. The films have a double discursive power, and are addressed to two publics whose understanding of the visual 
message is opposed by the very opposition of terrorism and resistance and the "cultural recognition" of each targeted group (Lambert 95).

Paul Virilio writes that: "there is no war without representation, no sophisticated weaponry without psychological mystification. Weapons are tools not just of destruction but also of perception." (Virilio 6) Hezbollah's strategies of representation while directed to the public of the $U s$ and the public of the Them aim to advance a narrative of selfempowerment by which the party seeks to subvert the prevalent discourse. In these films, there is, as we have seen in the analysis, a clear statement of power. The films are telling us, as "speech acts", or showing us, as "Gaze acts", a new power relation. It is precisely by representing an inverted relation of power, a narrative in which Hezbollah are showing themselves as the powerful that they can contend the dominant narrative.

On the one hand we have a public that is being consolidated in an Us by sharing images celebrating victory and power, perhaps even creating a common imaginary that consolidates the group, and on the other hand we have another targeted public, that of the them, for whom these videos operate as a Gaze seeking to be interiorized, as a disciplining force, or as weapons of perception.

By being directed to both Us and Them, these films carry a double message that puts forward the role of film and camera in war and conflict, both as a technological device in the perceptual fields and as a Gaze of power in the discursive field.

Foucault relates Gaze to the discourse of power. In this sense, to gaze is to enter power politics; it is a technique that allows the exercise of power on the one who is gazed at. The one who gazes holds a powerful objectifying look. The gaze can categorize, define (as an instrument of knowledge), control, subordinate, and threaten (as an instrument of power). The panopticon, described by Foucault in Discipline and Punish, represents the best analogy whereas the one who looks controls the one who is looked at by a mechanism of looking which enables the watcher to see without being seen while interiorizing the sense of being constantly watched. This form of surveillance, or for that 
matter surveillance in all its forms, makes it possible to qualify, classify, but also to discipline. Foucault writes that "in order to be exercised, this power had to be given the instrument of permanent, exhaustive, omnipresent surveillance, capable of making all visible, as long as it could itself remain invisible" (Foucault 1979, 214).

In the context of the Panopticon, the Gaze, its interiorization and the economy of power are three fundamental elements to the exercise of power. While in the panopticon the gaze and its interiorization are directed to inmates who are already subjugated to the institutional power, the similarity to Hezbollah's gaze in the filmed operations is seen as a resistance strategy that seeks this domination, or rather the exercise of power, over a stronger other, namely the Israeli army and public. The films' viewpoints are telling the other's public "we can see you wherever you are". This gaze thus seeks its interiorization in the mind of the other - the Israeli public - as a way to exercise power. This is one of the fundamentals of psychological warfare, which as it appears in the examination of Hezbollah's strategy, is a large part of their military efforts. In short, these films when directed to the Israeli public can acquire a disciplining force. And discipline in Foucault is a type of power, a modality for its exercise. It comprises a whole set of instruments, techniques, procedures, levels of application, targets, what Foucault will call a physics or an anatomy of power (Foucault 1979, 215).

Surveillance in the context of the panopticon is effective especially in terms of the economy of power and the cost needed to exercise such power. In this sense, Foucault's remarks about the little cost of power in the case of the panopticon relates directly to the economy of power by which the Hezbollah are required to exercise their power on the Israeli other. The films put forward a panoptic relation based on the notion of interiorization of the gaze as a way to ensure the exercise of power with the least possible cost both in financial terms and in terms of the economy of violence whereas an act of violence that is shown in a certain way can have a much bigger effect than a bigger act of violence that is not shown as efficiently in the aim of instilling fear in the minds of the viewers (Foucault 1980). On the other hand, the videos operate as a common imaginary that sustains and reaffirms the group narrative of identity by advancing an image of a 
powerful self that pertains to a system of values proper to the party's community of supporters. These films are providing the visual confirmation of Hezbollah's discourse of "resistance" which is constantly trying to give the Arab audience a sense of empowerment within a conflict in which they had historically seen themselves as its victims.

\section{Bibliography}

AJEMIAN, Pete (2008) Resistance Beyond Time and Space: Hizbullah's Media Campaigns. In Arab Media and Society (http://www.arabmediasociety.com/?article=671)

CHOMSKY, Noam, Foucault, Michel debate (1971) Human Nature: Justice versus Power. http://www.chomsky.info/debates/1971xxxx.htm)

CORM, Georges (2006) La Question Religieuse au XXIe Siècle. Paris : La Découverte

DAWISHA, Adeed (2005) Arab Nationalism in the Twentieth Century: From Triumph to Despair. Princeton University Press

DAYAN, Daniel (2006) La Terreur Spectacle: Terrorisme et Télévision. Paris : De Boek Université

DELEUZE, Gille (2004) Foucault. Paris: Les Editions de Minuit

EXUM, Andrew (2008) The Spectacle of War : Insurgent Video Propaganda and Western Response. in Arab Media and Society (http://www.arabmediasociety.com/index.php?article=672)

FOUCAULT, Michel (1971) L'Ordre du Discours. Gallimard

FOUCAULT, Michel (1979) Discipline and Punish: The Birth of the Prison. London: Penguin

FOUCAULT, Michel (1980) Power/Knowledge. Colin Gordon et al. New York: Pantheon

FOUCAULT, Michel (2004) Anthologie. Paris: Gallimard

FOUCAULT, Michel (2006) The Archaeology of Knowledge. London: Routledge

LAMBERT, Frédéric (1986) Mythographies. Paris: Edilig

MOHSEN, M., MZANNAR, A. (2001) Sourat al Moukawama fi al-I'lam: Hezbollah wa 
Tahrir Janoub Loubnan (The Image of Resistance in the Media: Hezbollah and the Liberation of the South of Lebanon). Beirut: Center for Strategic Studies, Research and Documentation

NASR, Vali (2007) The Shia Revival: How Conflicts within Islam Will Shape the Future. New York: W.W. Norton

NOE, Nicholas Ed. (2007) Voice of Hezbollah, The Statements of Sayyed Hassan Nasrallah. London: Verso

REVEL, Judith (2007) Dictionnaire Foucault. Paris: Ellipses

SAID, Edward (1978) Orientalism. London: Penguin Books.

SAMAHA, Joseph (1996) Salamon Aber (An Ephemeral Peace). Beirut: Dar Al-Nahar

TRABOULSI, Fawwaz (2007) Tarikh Loubnan al-Hadith (A History of Modern Lebanon).

VIRILIO, Paul (1989) War and Cinema. London: Verso

WODAK, R. and Meyer M. (2001). Methods of Critical Discourse Analysis. London:

Sage

ZIZEK, Slavoj (2006) The Parallax View. The MIT Press

Videos:

The Dabsheh Tank operation:

http://www.wa3ad.org/index.php?show=sounds\&action=play\&id $=198$

Storming al-Ahmadyeh outpost

http://www.wa3ad.org/index.php?show=sounds\&action=play\&id=192

Tallouseh outpost operation

http://www.wa3ad.org/index.php?show=sounds\&action=play\&id=183 